\begin{abstract}
Alicja Sakaguchi
Uniwersytet im. Adama Mickiewicza

\section{Poznanie poza językiem. Przypadek religijnego doświadczenia mistycznego a jego wysłowienie ${ }^{1}$}

\title{
Wstęp
}

Celem niniejszego artykułu jest spojrzenie na kwestię poznania i rozumienia z perspektywy świadomości mistycznej oraz pokazanie, w jaki sposób taki rodzaj świadomości manifestuje się w języku.

Materializacja i technizacja naszego życia oraz postępująca konsumpcja są wprawdzie pożądane i korzystne, ale jednowymiarowy „postęp” jest okupiony aż nazbyt wysoką ceną. Skutkiem tego rozwoju jest niedostrzeganie człowieka pneumatycznego (wewnętrznego) na korzyść czlowieka użytecznego, estetycznego (zewnętrznego). Przejawia się to zagubieniem głębszej świadomości, brakiem propozycji soteriologicznej oraz brakiem klucza hermeneutycznego (egzegetycznego) do zrozumienia i interpretacji tekstów sakralnych, w tym biblijnych.

Stoimy wobec zdumiewającego faktu: zjawiska tajemniczej przemiany człowieka i wypływającego z niej daru poznania o zupełnie innym rodzaju i innej jakości niż poznanie potoczne czy naukowe - poznania poszerzonego, pogłębionego, nazywanego przez mistyków i fenomenologów poznaniem całościowym lub integralnym. W tym osobliwym doświadczeniu duchowym mają udział niektórzy ludzie. Poznanie zaś będące owocem tego rodzaju doświadczenia, choć dość rzadkie, daleko wychodzi poza wiedzę ogólną polegającą na znajomości wielu faktów (ze świata materialno-zmysłowego i konwencjonalno-instytucjonalnego) i ich zależności. Wyższa wiedza (gnoza,

${ }^{1}$ Referat wygłoszony na konferencji naukowej dedykowanej Profesorowi Ludwikowi Zabrockiemu. Cykl konferencji poświęconych pamięci poznańskich językoznawców „Język a poznanie”, UAM, Poznań, 11-12.04.2011. 
gr. gnosis tou Theou - Mdr 1,132, sanskr. parâ vidyâ; ,sygnatura, na którą otwiera Duch" - Jakub Böhme) jest ściśle powiązana z Absolutem, Prawda objawiona, a także wiedza wlana albo - wyrażając to obrazowo - kluczami poznania, perła, skarbem lub duża ryba $a^{3}$. Okryte tajemniczością wydarzenie mistyczne jest zaś źródłem natchnienia prorockiego a zarazem punktem wyjścia powstania tekstów świętych, przede wszystkim tekstów profetyczno-objawieniowych samej Biblii.

Teologowie i filozofowie mistyki żywią przeświadczenie, że Bóg objawia swoją obecność pod dwiema różnymi postaciami: immanencją i transcendencją. Gdy mówią o immanencji, mają na uwadze Ducha Świętego przenikającego świat materialny; tę postać obecności Boga Grecy nazywali Pneuma, a Żydzi Szechiną. Transcendencja z kolei „dotyka” immanencji, bowiem, jak to wyjaśnia Abraham Heschel, „każde uchwycenie Boga jest pochwyceniem przez Boga, każde oglądanie Boga jest byciem oglądanym przez Boga"4. Z tego wynika, że wymiar wcielenia (czy urzeczywistnienia) uobecnia się na płaszczyźnie egzystencjalnej i świadomościowej i ma charakter praktyczny.

Mistycy uświadamiają nam nieustannie, że „nasze poznanie ma [wprawdzie - A.S.] znaczenie w świecie, ale nie w odniesieniu do [całego - A.S.] świata", tzn. sfery widzialnej i niewidzialnej ${ }^{5}$. Tymczasem człowieka Zachodu ogarnęła „racjonalna”, dogmatyczna świadomość dająca mu złudne poczucie samowystarczalności, a w zakresie nauki - obiektywności. Świadomość ta zamyka go w obrębie tego, co każdy tylko potocznie potrafi dostrzec, czego na

2 Jeżeli nie zaznaczono inaczej, cytaty pochodzą z Biblii Tysiąclecia (Pismo Święte Starego i Nowego Testamentu, Poznań-Warszawa 1990).

${ }^{3}$ Hugo ze św. Wiktora, dwunastowieczny filozof, teolog i autor traktatów mistycznych, przedłożył koncepcję oculus triplex 'potrójnego oka poznania' (Hugo de St. Victor, De sacramentis christianae fidei, Straßburg 1485, Pars Decime, Capitulum I). „Potrójne oko” obejmuje trzy wymiary, w których dokonuje się ludzkie poznanie. Okiem zmysłów człowiek postrzega materię, a „okiem racjonalnym” pojmuje rzeczywistość jeszcze szerzej i wnikliwiej. Dla mistyki jednak najistotniejszy jest trzeci wymiar poznania - poznanie, w którym człowiek przekracza zarówno doświadczenia zmysłowe, jak i myślenie pojęciowe i dyskursywne. Wyraża je metafora oculus contemplationis 'oko kontemplacji' albo 'oko duchowego widzenia' (łac. contemplatio 'ogląd', 'duchowe przypatrywanie się'). Otóż właśnie poszerzone czy pogłębione „widzenie”, współistotne z głębiami doświadczenia mistycznego, usposabia człowieka do oglądania Boga. Takie duchowe „oglądanie” czy „słuchanie” ma jednak zupełnie inną naturę niż samo myślenie o Bogu i o tym, jaki On jest. Zaś poszczególne etapy przemiany mistycznej, związane z nimi stany duchowe i owoce takiej przemiany nie dają się ani upojęciowić, ani adekwatnie wysłowić (jak dla przykładu jedna ze specyficznych treści takich doświadczeń, obrazowana przez mistyków jako duchowe ubóstwo, duchowa śmierć, wędrówka przez pustynię, noc ciemna czy przechodzenie przez nicość).

${ }^{4}$ A. Heschel, Die Prophetie, Kraków 1936, s. 182 (tłum. - A.S.).

${ }^{5}$ A. Reinach, Sämtliche Werke, München [1916] 1989, s. 602. 
co dzień może doświadczyć, względnie - co może zmierzyć i policzyć i co sam może skonstruować. Takie doświadczenie jest jednak częściowe, oderwane od całości rzeczywistości. Postulat obiektywnego badacza zatem, wysuwany przez wielu współczesnych naukowców, jest jako taki iluzją. Jest więc wysoce zaskakujące, że typ człowieka mistycznego, oświeconego prawie nie istnieje w świadomości przeciętnej jednostki kręgu zachodniego.

Dostąpienie Prawdy w życiu doczesnym - tego, co niezmienne, ponadczasowe, uniwersalne i miarodajne - to bezpośredni przekaz poza pismami. Dlatego mistycy, którzy widzą to, czego inni właśnie nie widzą, świadczą o istnieniu ,innego”, bardziej pojemnego świata. Świat ten obejmuje sferę nie tylko materialną i zmysłową, podlegającą instytucjonalizacji i konwencjonalizacji $^{6}$, ale i nadsubstancjalną, duchową, niepodlegającą ludzkiej myśli, ludzkim punktom widzenia, ludzkiej kontroli i organizacji.

Jestem przekonana, że mistyka i proroctwo są z gruntu rzeczy możliwą drogą każdego człowieka do porządku wyższego - do otwarcia, wzniesienia się i udziału w tym, co całkowicie inne (symbolizowanego przez spojrzenie ku niebu i wniebowstapienie). Jest to perspektywa odnalezienia naszej właściwej tożsamości poza uwarunkowaniami psychicznymi i społeczno-kulturowymi z ich redukcjonizmem poznawczym. Najwyższe duchowe poznanie i zdolność pogłębionego rozumienia i rozróżniania (gnoza) - jako dar spotkania z Bogiem - oddziałuje na świadomość poszerzonej rzeczywistości (gr. gnosis tou Theou; pol. teognozja, poznanie Boga lub Prawdy); jeżeli jednak człowiek nie ma udziału w przeżyciu i poznaniu mistycznym - brak tej świadomości (agnozja ${ }^{7}$ ). Człowiek mistyczny poprzez swoją więź z Bogiem uwewnętrznia religię i jej wymogi etyczne. Stąd prorocy i mistycy nieustannie nakierowują ludzi na drogę mądrości, prawości, sprawiedliwości, rozwagi i bezinteresowności wobec człowieka. Nie powinniśmy zatem tracić z oczu, że osadzenie człowieka między dobrem i złem nieuchronnie należy do jego natury.

${ }^{6}$ Ta sfera życia dotyczy takich spraw, jak zdobywanie wykształcenia, ustanawianie granic państwowych, nadawanie tytułów naukowych, zakładanie przedsiębiorstwa czy stowarzyszenia, wydawanie wyroków sądowych czy beatyfikowanie i kanonizowanie.

${ }^{7}$ Wyrażenie Theou agnosia występuje w Księdze Mądrości w kontekście najostrzejszej krytyki bezbożności zarejestrowanej na kartach Starego Testamentu. Autor tej księgi uświadamia nam, że Theou agnosia jest najistotniejszą przyczyną samoubóstwienia i idolatrii (por. B. Poniży, Znaczenie „Theou Agnosia” w Księdze Mądrości, w: Studium Scripturae anima theologiae, Kraków 1990, s. 248-259). To zaś może doprowadzić do katastrofalnych następstw z zagrożeniem pokoju na świecie. 


\section{Granice wyrażalności języka a poznanie}

Oczywiste jest, że umysł formowany wyłącznie od zewnątrz, uprzedzony, nie jest w stanie zobaczyć, a zatem i zrozumieć, niczego nowego. Aby zrozumienie mogło zaistnieć, konieczne jest, by zakorzenione asocjacje i wyobrażenia nie przysłaniały i nie deformowały postrzegania. Język z jego stereotypowymi wyrażeniami i konotacjami oraz z góry przyjętymi konwencjonalnymi pojęciami niewątpliwie ogranicza poznanie.

Aby człowiek mógł się wznieść wyżej, dostąpić Dobrej Nowiny, musi wyjść poza siebie i dosięgnąć jej poza granicą własnych czy cudzych opinii, poglądów, stereotypów, nawyków, podziałów i ograniczeń języka. Mikołaj z Kuzy radzi: „Ten zaś, kto pragnie dotrzeć do sensu, powinien raczej swój umysł wznieść ponad znaczenia i cechy słów, niż trzymać się ich uparcie"». Podobnie radzą mistrzowie zen: „Nie szukaj prawdy, lecz uwolnij się od twoich poglądów". Autor Ewangelii Filipa (EwF, log. 11) z kolei ostrzega swoich adresatów, zwłaszcza zaawansowanych na ścieżce duchowej, przed posługiwaniem się językiem ludzkim - językiem potocznego doświadczenia, narażonym na arbitralne zmiany znaczeń wyrażeń, nieuchronnie kształtowanym przez epoki, nurty, szkoły, tradycje, trendy, media, a także nieporozumienia. Język jako wytwór ludzkiej kultury ma swoje granice, podobnie jak swoje granice ma umysł. Można więc tutaj zauważyć, że kierujący się światłem poznania transcendentnego mistycy są bardzo ostrożni wobec wszystkiego, co miałoby jakikolwiek związek z tym, co ziemskie, a zatem kruche, niedoskonałe i przemijające. Dlatego nietrudno zrozumieć, dlaczego autor Ewangelii Filipa przestrzega przed „grzechami językowymi”, wyrażając tym samym obawę przed zatarciem granic między tym, co boskie, a tym, co ziemskie, a zatem wytwarzane przez ludzką myśl i wyobraźnię. Transcendentne, a więc wychodzące poza wszelkie zjawiska ograniczone, rozsadzające skostniałe pojęcia i konwencje, jest w tekstach gnostyckich tym, co skrajnie inne niż ,ten świat". Niektórzy mistycy wczesnochrześcijańscy, jak przywołany tutaj autor Ewangelii Filipa, byli szczególnie wyczuleni na kwestie semantyki języka profetycznego. Usiłowali oni zatem przedstawić nieadekwatność i ograniczoność ludzkiego języka próbującego ukazać to, co nadziemskie.

Proroctwo i mistyka jest na Zachodzie zjawiskiem dzisiaj bardzo zaniedbanym i mało znanym, a dar duchowego widzenia wraz z kwestią wyrażania go w języku został usunięty z dyskursu czy to religijnego, czy to naukowego na margines jako mało istotny lub nawet niewygodny. Zamiast tego wyłania

${ }^{8}$ Mikołaj z Kuzy, O oświeconej niewiedzy, Kraków 1997, s. 48. (Oryginał: De docta ignorantia, około 1440). 
się obecnie na plan pierwszy kultura, odgrywająca rolę „duchowego” substytutu. Kultura staje się metaforą wartości, jednoczącą orientacją społeczną w obrębie danego obszaru, np. geograficznego. Ten stan rzeczy tłumaczy, że zło jest zwykle kojarzone z takimi zjawiskami jak choroba, wojna, globalizacja, systemy polityczne, zanieczyszczenie środowiska czy niesprawiedliwość społeczna, a nie z kruchością samego człowieka, jego niewiedzą i nieświadomością odnośnie do swoich prawdziwych korzeni. Poza tym skupienie się na świecie zmysłowo-fizycznym przysłania nam szerszy i głębszy świat, a tym samym pozbawia kontaktu z rozległą częścią rzeczywistości: ziemskiej (widzialnej) i transcendentnej (niewidzialnej). Gdy jednak racjonalista ogranicza rzeczywistość do przyziemnego ludzkiego doświadczenia, konwencjonalnej wiedzy, oczywistości zjawisk i utworzonych przez siebie założeń, pojęć i teorii, odbiera życie wyższym sferom poznania i działa nierozważnie, wręcz niemoralnie. Doświadczenie mistyczne jako przeżycie pierwotne człowieka natomiast otwiera ludzi na transcendencję, na ,głos z nieba” (Mt 3,17), na „głos wychodzący od tronu” (Ap 19,5), na powrót do „domu Ojca mego” (J 14,2), na „poznanie boskiej sygnatury” - Böhme. Człowiek bowiem może mieć udział w czymś, co przekracza jego normalną kondycję, jest wyższe niż on sam i jego doraźne cele. Wynikiem takiego doświadczenia jest dar specyficznego poznania i pogłębionego rozumienia (gnosis tou Theou), który uzdalnia człowieka do wyjścia poza skostniałe struktury społeczne i ustalenia instytucjonalne, zastałe wzory myślenia i postępowania oraz światopoglądy, w końcu poza potocznie rozumianą kulturę. Człowiek natomiast, który miał udział w doświadczeniu mistycznym, potrafił je sobie przyswoić i na nie odpowiedzieć, jest głęboko przeświadczony, że jest ono najdonioślejszym wydarzeniem w jego życiu i ma znaczenie dla biegu historii. Jest to religijność w najintymniejszej, najgłębszej i najwyższej formie, co akcentuje psalmista w swoim apelu: „Skosztujcie i zobaczcie, jak dobry jest Pan" (Ps 34,9).

\section{Homo mysticus}

Mistyków i proroków możemy znaleźć na wszystkich obszarach geograficznych i we wszystkich kręgach kulturowych: wśród zakonników, zakonnic, księży, rabinów, sufich i osób świeckich, kobiet i mężczyzn - osób z bardzo różnym poziomem wykształcenia i w bardzo różnym wieku. Należy tutaj koniecznie zaznaczyć, że nie determinanty fizyczne, biologiczne czy społeczno-kulturowe (jak np. współczynnik inteligencji, zasoby wiedzy erudycyjnej, wychowanie, sprawowane funkcje, popularność czy przynależność do jakiejś wspólnoty, np. narodowej, etnicznej czy konfesyjnej), lecz osobliwe, zdumie- 
wające i niemożliwe do przewidzenia doświadczenia i działania nadają życiu pochwyconych Bożą ręką mistyczny a zarazem historyczny charakter. Należą do tej grupy prorocy starotestamentowi, np. Izajasz, Jeremiasz czy Ezechiel, nowotestamentowy Jezus z Nazaretu, gnostycy, np. Walentyn, postacie pobiblijne z kręgu np. chrześcijańskiego i islamskiego, jak św. Paweł, Orygenes, św. Augustyn, Mohamed, Hildegarda z Bingen, Muhjī ad-Dīn Ibn Arabi, Mistrz Eckhart, św. Teresa z Ávila, Marcin Luter, Jakob Böhme czy mistycy współcześni jak, Ojciec Pio, św. Faustyna Kowalska, Thomas Merton czy Anthony de Mello. Właśnie przekroczenie bariery dzielącej Boga i człowieka wyróżniły ich w aspekcie duchowym z grona wszystkich innych ludzi. Są oni naocznymi świadkami osiągnięcia głębszego źródła poznania (gnoza), dotarcia do przemieniającej życie świadomości mistycznej i stanięcia w obliczu powierzonego im przez Boga zadania.

Obdarzeni Duchem Bożym spoglądają na świat od wewnątrz, z perspektywy własnej potężnej przemiany duchowej. Ogarnięcie i zrozumienie całego ludzkiego doświadczenia (ziemskiego i transcendentnego) stoi przed nimi otworem. Zaś polem dla poczucia oświecającej więzi z niewidzialnym jest praktyczne działanie, przejawiające się w pisarstwie religijnym i naukowym, nauczaniu, przewodnictwie duchowym, kaznodziejstwie, reformach życia społecznego, zwłaszcza religijnego, oraz innych formach działalności ${ }^{9}$.

\section{Świadomość, poznanie mistyczne a język}

Udział w świadomości mistycznej, synoptycznej (gr. synopsis: syn- 'razem' i opsis 'widzenie') czy transpersonalnej oddziałuje bardzo osobliwie na sposób wysławiania i komunikowania się ze światem. Aby móc możliwie jak najadekwatniej oddać całkowicie „inne” przestrzenie rzeczywistości, które stają się udziałem mistyków, stosują oni bardzo specyficzne środki językowe, znacznie różniące się od używanych potocznie. Dla wyrażenia rzeczywistości transcendentnej używają środków retorycznych, takich jak: wyrażenia obrazowe, alegorie, antytezy, binarne wyrażenia łączące ze sobą przeciwieństwa ${ }^{10}$, para-

${ }^{9}$ Por. A. Sakaguchi, Język - mistyka - proroctwo. Od doświadczenia do wystowienia, Poznań 2011.

${ }^{10}$ Binarne, dwuskładnikowe wyrażenia łączące przeciwieństwa są też nazywane antytezami mistycznymi. Polegają one na zniesieniu opozycji (łac. coincidentia oppositorum 'łączenie ze sobą przeciwieństw', sanskr. advaita: a 'nie' i dvaita 'dwoistość', 'dualizm'). Mistycy posługują się często przeciwieństwami, które w wyniku dynamiki aktu przeżycia mistycznego czy - jak to wyraża Heschel (op.cit., s. 123) - „intensywności transcendentnej” prowadzą do przezwyciężenia opozycji, a więc także obu perspektyw immanencji i transcendencji, 
doksy, analogie, przypowieści, metafory, negacje, wyrażenia uniwokacyjne, cytaty biblijne, metonimie, hiperbole, paralelizmy syntaktyczne i powtórzenia, chiazmy, pytania retoryczne i korektywne ${ }^{11}$. Niektórzy autorzy uciekają się też do własnej inwencji językowej (słowotwórstwo, szczególnie Mistrz Eckhart), a także do zapożyczeń (zwłaszcza greckich i łacińskich).

Choć mistyk nie może swojego najgłębszego przeżycia religijnego dzielić z innymi, a więc z tymi, którzy takim doświadczeniem nie dysponują, to jednak jego wglądy i nauki są dostępne dla każdego, kto jest gotowy przypatrzyć się własnemu dojrzewaniu wewnętrznemu i kto chce zgłębić sens duchowego wzrostu i oświecenia.

Dla mistyka odmienność języków, zwyczajów i kultur nie jest przeszkodą w formułowaniu swoich najgłębszych doświadczeń i przesłań, ponieważ treści, w których ma udział, są zasadzone na bazie archetypowej, niepodlegającej zewnętrznym czynnikom (z ich ograniczeniami, konwencjami i ziemskimi punktami widzenia). Komentarz mistyka dotyczący tekstów świętych oraz pism autorów natchnionych jakichkolwiek obszarów geograficznych czy kulturowych będzie w istocie komentarzem uniwersalistycznym. Jest to możliwe dzięki wewnętrznemu metajęzykowi semantycznemu, którym mistyk lub prorok dysponuje, innymi słowy: istotowemu ,językowi” pozaleksykalnemu. Na tego rodzaju metajęzyk wskazuje w drugim liście do Tymoteusza sformułowanie ,wszelkie pismo od Boga natchnione” (2 Tm 3,16) oraz następujące po nim wyjaśnienie: „pożyteczne do nauczania, do przekonywania, do poprawiania, do kształcenia w sprawiedliwości”. Także metafora biblijna „mówić nowymi językami” (Mk 16,17) zdaje się odnosić do takiej właśnie rzeczywistości.

Uwagi te nasuwają stwierdzenie, że język mistyczny to język jednostkowy, specjalistyczny, nie zaś język społeczny w potocznym rozumieniu. Oświecające światło nadaje językowi prorockiemu i objawieniowemu szczególne właściwości, a cytaty biblijne i autorytet Słowa Bożego jeszcze większej pewności temu, co mistycy znają z własnego doświadczenia.

\section{Akty transcendentne (sakralne): ich natura i kwestie metodologiczne}

W przeciwieństwie do dziedzin świeckich istota komunikatu mistyków nie polega ani na przekazywaniu wiedzy wyuczonej, ani na komunikowaniu wy-

nieświadomego i świadomego, zależności i wolności, ducha i materii, tego, co metafizyczne, i tego, co historyczne.

${ }^{11}$ Por. A. Sakaguchi, Język - mistyka - proroctwo... 
tworzonej przez jednostkę myśli, koncepcji, poglądu, osobistego upodobania czy nastawienia, ani na przedstawieniu jakichś obrazów świata lub wyobrażeń o nim. Poznanie, które staje się udziałem mistyka czy proroka, wykracza dalece poza granice konwencjonalnie rozumianego poznania i rozumienia (zob. przypis 3). Mistycy, jak wynika z ich pism i świadectw, są w pełni świadomi takich spraw i stanów rzeczy, które wymykają się myśleniu pojęciowemu i dyskursywnemu. Takich treści nie sposób nawet wyrazić symbolicznie. Możemy tu jedynie wykorzystać arsenał archetypowych odniesień, to znaczy uniwersalnych „struktur” istotowych (nieposiadających form, postaci). Manifestacje jednego i tego samego prawzoru (np. doznanie przez człowieka siły działania transcendencji) są w dziejach ludzkości do siebie podobne lub analogiczne. Poprzez archetyp mistyczny zostaje wyrażone coś, co leży poza sferą ekspresji i komunikacji werbalnej, jak dla przykładu faza aktu przeżycia mistycznego, w której dokonuje się uwolnienie i oczyszczenie ze zjawisk i czynników będących przeszkodą w postrzeganiu rzeczywistości. Jest znamienne, że w tym tajemniczym zjawisku lub wydarzeniu zostają znacznie ograniczone albo całkowicie usunięte $\mathrm{z}$ umysłu koncepcje, wyobrażenia, a także wierzenia. W wyniku tego człowiek wyzuwa się z obrazu samego siebie i uwalnia się od złudzeń, pozorów, iluzji i mentalnych konstruktów opanowujących umysł, by się otworzyć na niczym niezmąconą rzeczywistość. Nawet jeśli taka przemiana jest dla osób nieobeznanych ze zjawiskami mistycznymi trudna do pojęcia, chodzi tutaj o fazę i stan wewnętrznego oczyszczenia w następstwie via purgativa. Ostatecznie tylko ten moment może uchronić ogół wiernych przed iluzją, że można Boga i jego siły zamknąć w sztywnej definicji. Już prorok Izajasz pytał ze wzburzeniem: „Do kogóż to porównacie Boga, i jaki obraz zastosujecie do niego?" (Iz 40,18; por. też zakaz tworzenia obrazów Boga w Wj 20,4-5, a także Koran 112:4). Podobnie Jan Apostoł ostrzegał chrześcijan w I wieku n.e.: „Dzieci, strzeżcie się fałszywych bogów!” (1 J 5,21).

Warto zwrócić uwagę na kilka kwestii natury metodologicznej. Otóż językoznawcy są od niepamiętnych czasów narażeni na niebezpieczeństwo beztroskiego wiązania swoich wypowiedzi o języku z ideami światopoglądowymi, prądami myślowymi lub poglądami filozoficznymi, czego wyrazem są koncepcje, orientacje i szkoły lingwistyczne, zwłaszcza nurty badawcze ukierunkowane kulturowo-cywilizacyjnie. Przykłady: siedemnastowieczne próby stworzenia ,gramatyki filozoficznej”, w których język był brany pod uwagę wyłącznie z perspektywy rozumu i logiki; nurt romantyczny - język jest w nim przedstawiany jako przejaw „ducha” narodu (Volksgeist), a w Sprachinhaltsforschung jako duchowy czynnik kształtowania rzeczywistości (wirkende Kraft, energetische Sprachbetrachtung); teoria relatywizmu językowego - przekonanie, że używany język wpływa na myślenie i sposób widzenia świata; współczesna 
„lingwistyka antropocentryczna” - koncentruje się na czynnikach zewnętrznych (kultura, instytucja, tradycja, kolektywny wymiar świadomości, np. common sense, mainstream). Płaszczyzną wspólną dla większości wymienionych tu orientacji jest przekonanie lingwistów o oddziaływaniu języka i kultury na wewnętrzną konstytucję człowieka przy równoczesnym pomijaniu innych możliwości, czynników i związków (istotnych dla oglądu i analizy języka np. sakralnego, w tym biblijnego).

Starania badawcze językoznawców cechuje ponadto dylemat pogodzenia całości zjawisk językowych, a więc aktów mowy świeckich i sakralnych, ze skostniałymi pojęciami i zakorzenionymi sądami naukowców, nie pomijając budzących zastrzeżenia i wątpliwości sposobów podejścia do kwestii samego języka, zwłaszcza profetycznego i mistycznego. Kto się jednak odważy zgłębić i opisać język proroków i mistyków, będzie nieuchronnie borykał się z trudnościami, zwłaszcza silnie zakorzenionymi uprzedzeniami i uproszczeniami współczesnych naukowców, wynikającymi ze wspomnianych deficytów i ograniczeń. Omawiane tu problemy dotyczą także psychologii ${ }^{12}$. Dlatego, po pierwsze, są konieczne usilne próby znalezienia takiego sposobu podejścia badaczy, który umożliwi adekwatne przedstawienie świadomości religijno-mistycznej, profetycznego, całościowego sposobu postrzegania człowieka i świata oraz właściwego im języka (bez redukcji, ograniczeń pojęciowych lub przypisywania takim sprawom i stanom rzeczy elementów niemających z nimi nic wspólnego). Po drugie, jest konieczne uświadomienie sobie także innych dróg poznania niż dotychczasowe. Niezbędne jest mianowicie wypracowanie takich instrumentów badawczych i sposobów opisywania rzeczywistości, które pozwoliłyby przezwyciężyć dylemat między wąską, potoczną wiedzą a rozumieniem, między instrumentami do opisu ograniczonych fenomenów świadomości a całym bogactwem doświadczenia mistycznego wraz z formami, w których się takie zjawiska manifestują. $Z$ tego wynika, że na doświadczenia i związki transcendentne oraz na język odzwierciedlający takie rzeczy i sprawy należy spoglądać inaczej niż w dotychczasowych, konwencjonalnych kategoriach odnoszących się do wiedzy, form i zjawisk w obrębie doświadczenia $\mathrm{z}$ „tego świata” (wymiar ziemski) - w przeciwieństwie do spraw „nie $\mathrm{z}$ tego świata" (wymiar transcendentny) - J 8,23.

Przemiany kulturowe i cywilizacyjne Zachodu doprowadziły do poglądów, że język warunkuje myślenie i postrzeganie, że tworzy czy generuje rzeczywistość, że ją ucieleśnia, a nawet że definiuje istotę bycia człowiekiem. Wobec tego ludzie poszukują dowodu na własne istnienie nie w przejściu na „inny” poziom ludzkich doświadczeń (chodzi tu o fenomen transcendencji, proroc-

${ }^{12}$ Por. K. Albrecht, Psychologie des mystischen Bewußtseins, Bremen 1951. 
two, mistykę, ekumenizm, postrzeganie całościowe), lecz opierając na założeniu, że „myślą" i mają ,język”. Wyraża się to w stwierdzeniach i maksymach typu ,język - fenomen definiujący człowieczeństwo”, ,język - fenomen najbardziej i najgłębiej ludzki", a także błędnych, groteskowych twierdzeniach, jak: ,język prowadzi do Sacrum”; „Objawienie Boga dokonało się w języku ludzkim”; „Język (wpływa istotnie) na myślenie mistyków” czy „Umiejętności językowe otwierają człowiekowi bramę do duchowości"13.

Samowystarczalność człowieka tworzącego własne alternatywy postępu, mądrości, zbawienia i szczęścia oraz jego podatność na bodźce zewnętrzne przejawia się na Zachodzie w niewspółmierności występowania elementu intelektualno-racjonalnego i kulturowego, w tym ideologicznego. W wyniku tego dyspozycje duchowe, określane współcześnie mianem „kapitału ludzkiego", są głównie upatrywane w stopniu wykształcenia, inteligencji, pomysłach, umiejętnościach, pracowitości oraz gromadzeniu wiedzy ${ }^{14}$. Lecz rozum posiada, jak wiadomo, zdolności przede wszystkim porządkujące, a nie poznawcze. Umysł nie jest też źródłem darów ducha (charyzmatów), jedynie wskazuje na wartości. Aby to sobie uprzytomnić, przyjrzyjmy się tekstom sakralnym.

\section{Świadomość działania Boga i wyrażenie poszerzonego poznania $\mathrm{w}$ języku}

W biblijnych tekstach profetycznych i objawieniowych, a także w pismach mistyków pobiblijnych, spotykamy osobliwe wyrażenia i sformułowania, np.:

- „być na obraz Boży” (por. Rdz 1,26-27; Mdr 2,23);

- „oglądać oblicze Boga” (por. Pwt 16,16; Ps 11,4-7);

- „Gdy nie ma widzenia [objawienia prorockiego - A.S.], naród się psuje” (Prz 29, 18);

- „Jakże ciasna jest brama i wąska droga, która prowadzi do życia, a mało jest takich, którzy ją znajdują!" (Mt 7,14);

- Powiedział Jezus: „Ja bowiem od Boga wyszedłem i przychodzę. Nie wyszedłem od siebie, lecz On mnie posłal. Dlaczego nie rozumiecie mowy mojej?" (J 8,42-43).

Źródłem wszystkich przytoczonych tutaj wypowiedzi jest akt doświadczenia mistycznego, zwanego także objawieniem, proroctwem i oświeceniem, na których ,wyrażenie brakuje słów”, co zaznacza św. Jan od Krzyża ${ }^{15}$.

${ }_{13}$ U.M. Nix, Der mystische Wortschatz Meister Eckharts im Lichte der energetischen Sprachbetrachtung, Düsseldorf 1963, s. 57, 63, 79 (tłum. - A.S.).

${ }_{14}$ Por. T. Sarrazin, Deutschland schafft sich ab, Monachium 2010, s. 52.

15 Jan od Krzyża, Żywy ptomień miłości, Kraków 2003, s. 18. 
Mistyk lub prorok czuje potrzebę wypowiadania pewnych doniosłych dla życia człowieka rzeczy. Wyrażenia (zaznaczone wyżej pogrubioną czcionką) być na obraz Boży, ogladać oblicze Boga, widzenie, ciasna brama lub od Boga wyszedtem należą do szczególnego rodzaju słownictwa, które określam tutaj mianem sakraliów ${ }^{16}$. Sakralia odnoszą się do realiów nadziemskich (transcendentnych) i do sfery rzeczywistości sakralnej ${ }^{17}$. Rzeczywistość ta wymyka się sferze materialno-zmysłowej i instytucjonalnej z jej codziennym, konwencjonalnym doświadczeniem i rozumowaniem. Jednak mistyk doświadcza działania mocy Boga jako uchwytną i możliwą do zrozumienia rzeczywistość, która ostatecznie przyjmuje postać zewnętrzną, a więc formę językową. Prorok lub charyzmatyczny mistyk świadczy o tym wymiarze rzeczywistości, a jego mowa zawiera przekaz od Boga dla ludu (Stowo Boże). Sakralia nie są jednak pojęciami, które można byłoby ująć w sztywne definicje, w przeciwieństwie do niektórych pojęć doktrynalnych i instytucjonalnych np. Kościoła katolickiego, jak epikleza, konsekracja, transsubstancjacja czy Kongregacja do spraw Nauki $i$ Wiary. Sakralia przysparzają jednakże wielu ludziom trudności w zrozumieniu albo wywołują bardzo często nieporozumienia.

Należy pamiętać, że istotną cechą mistycznego aktu świadomościowego jest inspiracja prorocza ${ }^{18}$. To bowiem, co objawiają mistycy i prorocy, jest wiedzą z pierwszej ręki, nie zaś wiedzą z książek czy zapośredniczoną od innych. Prorocy i mistycy zabierają głos nie jako wyszkoleni teolodzy, lecz jako oświeceni, obdarzeni spontanicznością i natchnieniem autorzy, będący w pełni świadomi swego szczególnego zadania w świecie. Jak wyżej wspomniano, w samym akcie mistycznym słowa, pojęcia i wyobrażenia milkną. Ale rzecz w tym, że większość mistyków nie jest w stanie milczeć i ich doświadczenie musi być wypowiedziane - choćby z pomocą środków niekonwencjonalnych i często za cenę irytacji oraz trudności w zrozumieniu ze strony odbiorców. $\mathrm{Na}$ trudność wyjawienia najgłębszych przeżyć i objawień, zwłaszcza wyrażenia ich w języku, wskazał już prorok Jeremiasz, który powołany przez Boga nie umiał nic powiedzieć. Jednak Bóg obdarzył go natchnieniem i rzekł mu: „Oto kładę moje słowa w twoje usta. Spójrz, daję ci dzisiaj władzę nad narodami i nad królestwami, byś wyrywał i obalał, byś niszczył i burzył, byś budował i sadził" (Jer 1,9-10).

${ }^{16}$ Tego typu słownictwo Erazm z Rotterdamu określał mianem „słowa mistyczne” (por. Erazm z Rotterdamu, Trzy rozprawy, przeł. J. Domański, Warszawa 1960, s. 257).

${ }^{17}$ Por. A. Sakaguchi, Język - mistyka - proroctwo..., s. 262-276.

${ }^{18}$ Por. A. Heschel, op.cit. 


\section{Język mistyczny (prorocki) i akty mowy transcendentne: kilka uwag}

Charakterystyczne dla mistyków i proroków akty mowy to po pierwsze stwierdzanie istniejących stanów rzeczy (ziemskich i nadziemskich), a więc asertywy, takie jak: prorockie przepowiadanie, hymny pochwalne, wyznania mistyczne, wyjaśnienia (demaskowanie i korygowanie błędów - zwłaszcza poznawczych, porządkowanie zawiłości, wyjaśnianie nieporozumień, rozplątywanie niejasności, rozświetlanie mroków) czy skargi; po drugie performatywy, takie jak: błagania, prośby i modlitwy, pouczenia, wezwania, rady i przestrogi, napomnienia, dialogi między mistrzami duchowymi a ich uczniami, błogosławieństwa, groźby, nagany, zapowiedzi kary Bożej, a także zakazy. Treści ich pism unaoczniają nam, że nieustannie nakierowują ludzi na drogę prawości i bezinteresowności, niekiedy nawet narażając własne życie. Wypowiedzi mistyków i proroków są zawsze formułowane z perspektywy ich własnej, potężnej przemiany wewnętrznej i ich udziału w wiecznej, niezmiennej Prawdzie.

Przyjrzyjmy się tutaj jednemu z tych typów - wyznaniom mistycznym. Mistyk zaświadcza o nim, aby rozbudzić wrażliwość odbiorcy na świat duchowy, na rzeczywistość w jej poszerzonym wymiarze. Spójrzmy, jak obrazują poczucie Bożej mocy i doznanie oświecenia mistycy biblijni i pobiblijni i co mówi na ten temat Nowy Testament: Ezechiel - „Otworzyły się niebiosa i doświadczyłem widzenia Bożego” (Ez 1,1); Izajasz - „Ujrzałem Pana siedzącego na wysokim i wyniosłym tronie, a tren Jego szaty wypełniał świątynię" (Iz 6,1).

Względnie wczesne świadectwo w Dziejach Apostolskich prowadzi nas na ważny ślad Jezusa jako mistyka: ,Wiecie, co się działo w całej Judei, począwszy od Galilei, po chrzcie, który głosił Jan. Znacie sprawę Jezusa z Nazaretu, którego Bóg namaścił Duchem Świętym i mocą. Dlatego że Bóg był z Nim, przeszedł On dobrze czyniąc i uzdrawiając wszystkich, którzy byli pod władzą diabła" (Dz 10,37-38). Z tego dokumentu wynika niezbicie, że Jezus miał udział we własnym doświadczeniu mistycznym i działał, opierając się na nim. Wyrażenia Bóg namaścit Duchem Świętym i moca, Bóg byt z Nim, dobrze czynit, uzdrawiał wszystkich świadczą o tym, że Jezus dysponował doświadczeniem integralnym i świadomością profetyczną oraz że trwał w jedności z tym, którego nazywał moim Ojcem („Ja i Ojciec jedno jesteśmy” - J 10,30). Postrzegał siebie samego niewątpliwie jako proroka, jako „palec Boży” (Łk 11,20), który działa na „mocy Ducha Bożego” (Mt 12,28).

Opis Blaise'a Pascala z roku 1654 tak zaś odmalowuje jego przeżycia i obserwacje towarzyszące wstępowaniu na wyżyny mistyczne: „Ojcze sprawiedliwy, świat Cię nie poznał, ale ja Cię poznałem. Radość, radość, radość, łzy radości. [...] Pewność. Pewność. Uczucie. Radość. Pokój. [...] Ten tylko go 
znajdzie, kto pójdzie drogą wskazaną w Ewangelii”19. Faustyna Kowalska zarysowuje swoje doznania mistyczne za pomocą afektywnej ekspresji: „Czuję, jakoby wszystko odpadło od duszy mojej, jakobym dopiero wyszła z ręki Bożej, czuję nietykalność swojej duszy, czuję, że jestem dziecię maleńkie. Wtem ujrzałam wewnętrznie Pana, który mi rzekł: «Nie lękaj się, córko moja, ja jestem $z$ tobą»" ${ }^{20}$.

Baczne przyjrzenie się doświadczeniom, wglądom oraz orędziom mistyków i proroków z różnych epok odsłania rysy charakterystyczne dla ludzi mających udział w trwałym w skutki przeżyciu i poznaniu całościowym (lub integralnym). Tego rodzaju przemiana wewnętrzna i nowa świadomość oddziałuje zaś bardzo wyraźnie na sposób wysławiania i komunikowania się mistyków ze światem. Przyglądając się uważnie tekstom mistycznym, można zauważyć, że najistotniejszymi, a zatem kluczowymi środkami leksykalnymi tekstów autorstwa mistyków, apostołów i proroków są sakralia. Dotyczą one rzeczywistości nadziemskiej, ponadprzestrzennej, ponadczasowej, niezmiennej, archetypowej, a zatem obiektywnej (aczkolwiek doświadczanej subiektywnie), znajdującej się ponad myślą, kategoryzacją, pojęciem, kulturą i tradycją.

\section{Język mistyczny (prorocki): kilka przykładów środków retorycznych}

\section{Formuła przymierza: immanencja i transcendencja}

To, co jest najważniejsze, a zatem i nieustannie obecne w języku Starego i Nowego Testamentu (hebrajskim czy greckim), języku gnostyków i wielu pismach mistyków pobiblijnych, ogniskuje się nie wokół istoty czy idei Boga, lecz wokół Jego panowania i zbawczego działania. Relacyjność ta jest sygnalizowana za pomocą kategorii immanencji i transcendencji. Wskazują na to wyrażenia i wypowiedzi odnoszące się do wspólnoty lub przymierza z Bogiem, zamieszkiwania Boga wśród ludzi, bycia pod Jego panowaniem oraz wewnętrznej więzi i jedności z Nim. Ojciec Pio, posługując się wyrażeniami obrazowymi i analogią, mówi np. o sobie samym tak: „Serce Jezusa i moje własne - pozwól mi użyć tego wyrażenia - stopiły się. Nie było już więcej dwóch bijących serc, ale tylko jedno. Moje własne serce zniknęło, jak kropla wody ginie w morzu. Jezus był jego Rajem, jego Królem"21. Ta wypowiedź

19 B. Pascal, Rozprawy i listy, przeł. T. Żeleński-Boy, M. Tazbir, Warszawa 1962, s. 77-78.

${ }^{20}$ F. Kowalska, Dzienniczek, Warszawa 2002, s. 59.

${ }^{21}$ I. Niro, Ojciec Pio - święty z Pietrelciny. Świadectwa, cz. 1-3, San Giovanni Rotondo 2008-2010, s. 638. 
wyraża to, co teologia chrześcijańska określa mianem unio mystica - zjednoczenie w woli (z Bogiem) i odczuwaniu. Kategoria „przymierza z Bogiem”22 zasadza się na potencjale uchwycenia realności Boga przez człowieka („,obraz i podobieństwo Boga", Rdz 1,26-27; Mdr 2,23), a wcielenie Bożego prawzoru (doświadczenie mistyczne), jak obrazuje wypowiedź Ojca Pio, wyraża się właśnie w kategoriach immanencji i transcendencji.

Można rozróżnić dwa wymiary immanencji: publiczny lub eklezjalny (eschatologia powszechna) i jednostkowy (eschatologia jednostkowa, czyli indywidualna). Oba te wymiary: publiczny i jednostkowy bezustannie się przeplatają w Starym i Nowym Testamencie. Immanencja dotyczy: 1) atrybutów Bożych w człowieku (miłość, sprawiedliwość, mądrość), 2) drzemiącego w człowieku potencjału („obraz i podobieństwo Boga”, Rdz 1,26-27, pneuma bądź ,iskra Boża”) oraz 3) trwania człowieka w Bogu lub wspólnoty z Nim. Nie dysponujemy jednak kryteriami formalnymi, które pozwoliłyby ściśle opisać i scharakteryzować ten specyficzny środek wyrazu. Spróbujmy więc wskazać chociażby na kilka sposobów sygnalizowania immanencji.

W Starym Testamencie immanencja osiąga najbardziej wyrazistą postać w formule przymierza. W Księdze Kapłańskiej czytamy: „Będę chodził wśród was, będę waszym Bogiem, a wy będziecie moim ludem” (Kpł 26,12). Formuła ta otrzymuje zaś najbardziej wymowny wyraz w następującej wypowiedzi: „Przymierze moje, które zawieram pomiędzy Mną a tobą oraz twoim potomstwem, będzie trwało z pokolenia w pokolenie jako przymierze wieczne" (Rdz 17,7). Natomiast psalm 100 uniwersalizuje przymierze i wyraża je w formie imperatywu: „Wszystkie ziemie [...] stawajcie przed Nim!” (Ps 100,3). W historii formuły przymierza odzwierciedla się historia teologii przymierza, która w różnym stopniu akcentuje wzajemność albo jednostronność udziału w niej, tzn. słuchanie Boga i wierność Jemu albo ignorowanie Boga i przeciwstawianie się Mu. Przymierze ugruntowuje działanie Boga wśród swego narodu i dla niego: w wyjściu z Egiptu, w zamieszkiwaniu Boga między Izraelitami, w działaniu zbawczym ${ }^{23}$. W przymierzu z Bogiem tkwi sprzeciw wobec zbrodniczych, krzywdzących czynów jednostek i grup społecznych, przeciw nienawiści, tragicznej w skutkach obojętności, stronniczości i zaściankowości, przeciw nawrotom zła. Formuła przymierza wiąże się w niektórych miejscach z formulą samoprzedstawienia Boga: „Ja jestem Jahwe, twój Bóg” (Wj 20,2), „Ja jestem Pan, wasz Bóg” (Kpł 25,55), formułą rozpoznawczą, skierowaną do ludzi: „Pilnie słuchać będziecie głosu mego” (Wj 19,5), „Zamilk-

22 Przymierze odnosi się do układu dwustronnego między Bogiem a człowiekiem z inicjatywy Bożej. Sygnalizuje immanencję i transcendencję oraz zobowiązuje do wierności.

${ }^{23}$ Por. K. Scholtissek, In Ihm sein und bleiben, Freiburg 2000, s. 93. 
nij, Izraelu, i słuchaj!” (Pwt 27,9) oraz formułą zapewnienia zamieszkiwania Boga pośród swego ludu: „Ja jestem z tobą” (Iz 41,10), „Nie lękaj się ich, bo jestem z tobą, by cię chronić" (Jer 1,8). Formuły te stanowią najbardziej zwarte wypowiedzi Biblii, w których fundamentalne treści duchowe lub absolutne są sygnalizowane za pomocą niewielu słów.

Na obecność i bliskość Boga wskazują ponadto w Starym Testamencie czasowniki, takie jak być ujętym przez Boża rękę, mieć na sobie Boża rękę, osiaśś, lgnać, siedzieć, mieszkać, trwać lub znaleźć. Przykład: „Patrzycie z zazdrością na górę, gdzie się Bogu spodobało mieszkać, na której też Bóg będzie mieszkał na zawsze” (Ps 68,17). Również kluczowe pytanie biblijne „Któż zdoła stanąć przed obliczem Pana, przed tym Bogiem świętym?” (1 Sm 6,20) dotyczy wymiaru immanencji. Język wyrażający te treści i związki to nie język teorii, filozofii, mitu czy poezji, lecz język fenomenologii poznania albo dokładniej: język doświadczenia Boga.

\section{Wyrażenia obrazowe}

Wyrażenia czy pojęcia obrazowe (niem. Sinn-, Begriffsbilder) stanowią trzon tekstów mistycznych. W przypadku sakraliów mamy wprawdzie do czynienia z rzeczywistością ukrytą i niewidzialną, ale możliwą do uchwycenia poprzez znaki. Kluczowe sprawy związane z drogą do poznania Boga są zarysowane w Księdze Wyjścia w sposób obrazowy: „Oto ja posyłam anioła przed tobą, aby cię strzegł w czasie twojej drogi i doprowadził cię do miejsca, które ci wyznaczyłem. Szanuj go i bądź uważny na jego słowa. Nie sprzeciwiaj się mu w niczym [...], bo imię moje jest w nim" (Wj 23,20-21). Te słowa dotyczą wydarzenia, które może doprowadzić człowieka do „oglądania Boga” (Mt 5,8), do „Jego przebudzenia” ${ }^{24}$ (w sensie troski o wiedzę i zbawienie dla tych, którzy Go potrzebują), do „poznania sygnatury, na którą otwiera Duch” (Böhme) lub do „duchowej metamorfozy” (Ojciec Pio).

Słowa niebo i piekło zaś obrazują rzeczywistości duchowe w nas. W sensie teologii mistycznej nie są jednak określeniami miejsca, do którego mielibyśmy trafić po śmierci. Wyrażenie niebo odnosi się do bycia w bliskości z Bogiem, z zasadą nadającą światu kształt i porządek, wskazuje na realną możliwość dotknięcia Absolutu i zbawienie; piekło natomiast wyraża zamknięcie się w naszym życiu na to, co niesie uwolnienie i oczyszczenie oraz duchowy wzrost aż po stopień oświecenia i wewnętrznego pokoju. Na moment oczyszczenia i wyzwolenia z pęt świata wskazują z kolei wyrażenia obrazowe, takie jak „duchowe ubóstwo” (Mt 5,3), „noc ciemna” (św. Jan od Krzyża)

${ }^{24}$ Pseudo-Dionizy Areopagita, Imiona boskie. Teologia mistyczna, przeł. M. Dzielska, Kraków 1997, s. 205. 
czy „pustkowie wśród dzikiego wycia” (Pwt 32,10). W teologii mistycznej nazywa się to droga oczyszczenia (via purgativa) w sensie uwolnienia się od poglądów, uprzedzeń, wyobrażeń, stereotypów, nawyków i przyzwyczajeń, krótko: $\mathrm{z}$ tego wszystkiego, co nie jest istotą prawdziwej natury człowieka (czystego, nieuwarunkowanego JA). Duchowe ubóstwo, samoogołocenie lub noc ciemna, w których nie ma żadnego bytu, jest etapem przejściowym; zaś owocem uwolnienia i oczyszczenia mistycznego jest dotarcie do własnej Jaźni, poznanie Prawdy, królewska wolność ducha - św. Jan od Krzyża. Nie wolno zatem utożsamiać mistycznych wyrażeń obrazowych, takich jak pobyt na pustyni, wejście $w$ noc ciemna czy wniebowstapienie, z realiami potocznego życia ziemskiego, ani kojarzyć ich z jakimikolwiek światopoglądami, mitami czy doktrynami.

\section{Słowa o innym znaczeniem niż znaczenie ziemskie}

Ekwiwokacja (łac. vox 'głos’, ‘słowo', konkretnie: podwójne znaczenie, wieloznaczność) to stosowanie tego samego słowa w różnych znaczeniach. Język mistyczny czerpie swój materiał leksykalny, dokładniej: swoją (zewnętrzną) formę czy szatę językową, z języka używanego w najbliższym otoczeniu człowieka, a więc z języka rzeczywistości ziemskiej. Lecz w kontekście mistycznym wiele potocznych słów i wyrażeń ze sfery ziemskiej ma inne, mistyczne znaczenie, jak dla przykładu styszeć czy widzieć (słowa te znaczą tu nie słyszenie uszami ciała, lecz uszami duszy lub serca, podobnie jak widzenie nie znaczy tu widzenia oczyma ciała, lecz widzenie oczyma duszy). Inny przykład: ojczyzna (ojczyzna lub naród to słowa obciążone przez historię, szkołę, podręczniki, media, prasę, jednostronnie ukierunkowane książki; zaś w sferze aktów transcendentnych ojczyzna jest celem życia, najpełniejszym i najpomyślniejszym wyrazem splotu wydarzeń w sensie duchowym). Dalsze przykłady słów z innym znaczeniem niż znaczenie ziemskie to: życie, śmierć, sprawiedliwy, serce, skarb, perła, pole uprawne, owoc, napój, wolność, powołanie, arkanum czy eon. Słowa te zostają przeniesione ze sfery ziemsko-materialnej do sfery transcendentno-duchowej, co w konsekwencji prowadzi do powstania słów z innym znaczeniem niż potoczne znaczenie ziemskie.

\section{Przypowieść}

Przypowieść (hebr. $m \bar{a} \bar{s} \bar{a} l, m^{\mathrm{e}}$ šālîm, gr. parabolê 'porównanie') jest to najczęściej krótkie opowiadanie służące do zobrazowania pouczenia prorockiego. Przypowieść to obrazowa figura retoryczna posługująca się porównaniem, która ma na celu zilustrowanie spraw i stanów rzeczy zasadzonych na wiecznej Prawdzie i na historii zbawienia. 
W związku z rozważaniami mistyków dotyczących wewnętrznej kondycji człowieka, a zwłaszcza silnym akcentowaniem przez nich cechy kognitywnej 'zdolność rozróżniania', przytaczam tutaj przykład przypowieści z Ewangelii Tomasza, która powstała około dwóch tysięcy lat temu. Logion 8 tejże Ewangelii o rozumnym rybaku i jego nowotestamentowa paralela (przypowieść o sieci zagarniającej ryby, Mt 13,47-51) rozprawia o selekcjonowaniu i wybieraniu złowionych ryb. Podmiotem opowieści w Ewangelii Tomasza jest jednak nie grupa ludzi, lecz jednostka: rybak rozumny. Ponieważ w tej przypowieści chodzi o świadomość, konkretnie zdolność rozróżniania (,Wyrzucił wszystkie małe ryby do morza i bez trudu wybrał dużą rybę"), trudno tutaj nie zauważyć jakże ważnej perspektywy antropologicznej i profetycznej. Być rybakiem znaczy w kontekście profetycznym (czy mistycznym) wydobyć coś wartościowego na światło i wcielić to we własną egzystencję, a więc urzeczywistnić, zaktualizować. Znaczy to także, że po pierwsze jest się zdolnym uwewnętrznić to, co istotne, wysokie, sensowne, a po drugie umie się dokonać wyboru spośród wielu rzeczy, natłoku informacji, słów i myśli. Jeżeli owa „zdobycz” stanie się własnym ,pokarmem”, będzie ją można dzielić także z innymi. Małe ryby symbolizują w tej przypowieści to, co przeciętne i codzienne, a także iluzoryczne, duże, ładne ryby natomiast mądrość, oświecenie i gnozę. Wezwanie kończące to opowiadanie: „Kto ma uszy do słuchania, niech słucha!” (także Mt 13,9) jest niczym innym jak sformułowaniem obrazowym odnoszącym się do poszerzonej wiedzy duchowej, zawsze idącej w parze ze zdolnością rozumienia i rozróżniania. Te zaś stanowią bezsprzecznie najwyższą miarę i wartość ludzkiej egzystencji.

\section{Hiperbola}

Hiperbola (gr. hyperbolé, łac. superlatio, pol. przesadnia) jest to trop polegający nie tylko na przejaskrawieniu lub potęgowaniu spraw czy stanów rzeczy, lecz przede wszystkim na wyolbrzymieniu twierdzeń. Typowy przykład znajdujemy w Ewangelii wg św. Mateusza: „Przewodnicy ślepi, którzy przecedzacie komara, a połykacie wielbłąda!” (Mt 23,24). Autor ewangeliczny uzmysławia swoim adresatom, że przywódcy społeczeństwa koncentrują się na błahostkach i nie są zdolni rozpoznać tego, co jest w życiu istotne i konieczne.

Hiperbola służy także do wyrazu afektywności i wzmacnia wyrazistość prezentowanej treści, np. strzała lub rana mitości jako nieodzowny element inicjacji mistycznej i działania Boga. Jesaja wyznaje: „Uczynił [podmiotem mówiącym jest tutaj Bóg-A.S.] ze mnie strzałę zaostrzoną, utaił mnie w swoim kołczanie" (Iz 49,2), a Katarzyna z Genui: „To stworzenie [mistyk - A.S.] żyje ze strzał 
miłości, które mu zsyła Bóg”25. Bóg jest tutaj Łucznikiem (bądź Ofiarujacym), a prorok lub syn Boży (bądź ofiarowany) Strzała, a przez ranę, którą Bóg zadaje duszy, staje się On obecny i budzi w duszy pragnienie siebie. Nietrudno tutaj zauważyć, jak ważnym środkiem perswazji prorockiej jest hiperbola.

Także Henryk Elzenberg posługuje się nią często, by uprzytomnić swoim odbiorcom kontrasty naszego życia (nazywa je „tym światem”). Wyraża to tak: „Są na świecie bandyci i święci. Ale święci obracają się w ramach, które wyznaczają bandyci”26 lub: „Teozofia i kierunki pokrewne tak się mają do poważnej mistyki i do poważnej religii, jak grafomania do prawdziwej poezji. Teozofowie, to grafomani mistyki”" ${ }^{27}$. Elzenberg rozprawia się tutaj krytycznie z kwestią dotyczącą kompetencji, wiedzy i rozumienia spraw ze sfery mistycznej. Letniość i duchowy zastój z kolei, jakże charakterystyczne dla środowisk wiernych, np. katolickich, podążających swoją przeciętną koleiną, nazywa szyderczo „apostolstwem śmierci”; zorganizowane, masowe chrześcijaństwo - „organizacją Wielkiego Odczepnego dla Absolutu”, a kulturę - „heroiczną i nieudaną próbą nadania sensu życiu ziemskiemu bez oparcia o zaplecze metafizyczne"28.

Autorzy mistyczni posługują się hiperbolą, by móc zwrócić uwagę również na szczególnie bolesne deficyty i problemy społeczne oraz na wewnętrzną kondycję człowieka. W ten sposób chcą zaakcentować, jak doniosłe są kwestie podejmowane przez nich.

\section{Podsumowanie}

Podsumowując te rozważania, można stwierdzić, że natchnienie ksiąg świętych i pism mistycznych oraz charyzmat ich wyjaśniania są wynikiem daru proroctwa bądź świadomości mistycznej. Pierwiastek prorocki może się ujawnić w różnych formach (leksykalnych, syntaktycznych lub retorycznych) w zależności od predyspozycji autora natchnionego, częściowo także kręgu kulturowego i okresu, w którym żył. Przejawem natchnienia prorockiego są zaś wypowiedzi w funkcji informująco-pouczającej, perswazyjnej i ekspresywnej, a wyróżniającymi cechami takich wypowiedzi są m.in. ich hieratyczność oraz wysoki stopień pewności epistemicznej. Mistycy i prorocy osiągają w swoim duchowym widzeniu szczyt pewności, wyrażający się brakiem operatorów

${ }^{25}$ K. von Genua, Lebensbild und geistige Gestalt. Ihre Werke, München 1939, s. 235 (thum. - A.S.).

${ }^{26}$ H. Elzenberg, Kłopot z istnieniem, Kraków 1963, s. 284.

${ }^{27}$ Ibidem, s. 293.

${ }^{28}$ Ibidem, s. 329, 344, 423. 
przypuszczenia, domniemania, wątpliwości lub niewiary, a ich wypowiedzi mają charakter hieratyczny (z gr. hieratikos 'kapłański', 'namaszczony', hieratika 'święty') ${ }^{29}$. Pewność epistemiczna z kolei wyraża się: 1) w stosowaniu czasowników modalnych, trybu orzekającego, rozkazującego i optatywnego w czasie teraźniejszym, np. powiadam wam; ,błogosławieni ubodzy w duchu" (Mt 5, 3); chce, abyście wiedzieli; jestem najgłębiej przeświadczony/-na; „Wiem o tym, bo sama po wiele razy tego doświadczyłam...”30; „Spójrz, ślepy człowieku, chcę ci pokazać..."31 oraz 2) w stosowaniu partykuł epistemicznych implikujących i podkreślających prawdziwość wiedzy mówiącego, jak zaprawdę, doprawdy, na pewno, rzeczywiście, istotnie, otóż, zaiste, amen. Kryterium pewności epistemicznej ugruntowuje - obok innych kryteriów teologicznych i lingwistycznych - status aktów mowy sakralnych i stanowi także podstawę rozróżnienia aktów sakralnych i świeckich.

Biorąc pod uwagę naturę świadomości mistyka, jego zachowania i działania, język powinien się tutaj wyłonić jako specyficzna forma odzwierciedlenia jednostkowego przeżycia, natchnienia, duchowego poznania i powołania, a nie jako forma konceptualizacji i profilowania świata czy jako forma wpływu na postrzeganie świata (językowe obrazy świata, Boga, człowieka, a nawet samej mistyki). To rozróżnienie jest bardzo ważne ze względu na kryteria „wewnętrzny” i ,zewnętrzny”; „Duch boski” i „duch zwodniczy” bądź „duch niemocy”; ,prawda” i „pozór”, ,iluzja”; ,(czysta) rzeczywistość” (widzialna i niewidzialna) i ,(stwarzane) stany rzeczy”.

Przedstawione tu uwagi i rozważania mają na celu pokazanie kompleksowości przestrzeni poznania, a także zwrócenie uwagi na fakt, że wiedza transcendentna (gnoza) pochodzi z głębszych pokładów świadomości i że nie jest uwarunkowana ani społecznie, ani kulturowo. Taka wiedza dotykająca Absolutu jest wręcz podstawą i źródłem człowieczeństwa, a także punktem wyjścia wszystkich nauk. Jak nam bowiem uświadamia Edmund Husserl: wszystkie możliwe kwestie filozoficzne i naukowe należy stawiać i rozstrzygać z perspektywy otwartego w swojej nieskończoności transcendentnego gruntu doświadczenia $^{32}$.

Wpływ języka na myślenie i zachowanie dotyczy według mnie wyłącznie świadomości w obrębie ,tego świata”. Przedstawione tutaj rozważania mają na celu uzmysłowić, iż nie każdy rodzaj poznania jest sprzężony z językiem

${ }^{29}$ Więcej szczegółów na ten temat znajduje się w rozdz. VIII (Fenomenologia aktów mowy w tekstach mistyków) w: A. Sakaguchi, Język - mistyka - proroctwo...

30 Teresa od Jezusa [z Ávila], Twierdza wewnętrzna, Kraków 1943, s. 142.

31 J. Böhme, Die Morgenröte bricht an, Freiburg 1983, s. 23 (tłum. - A.S.).

32 Por. E. Husserl, Die Krisis der europäischen Wissenschaften und die transzendentale Phänomenologie, Hamburg [1934-1937] 1996, s. 111-112. 
i że człowiek potrafi wyjść z ,niewoli języka” i tym samym uwolnić się od zależności psychicznych, uwarunkowań społecznych i myślenia pojęciowego. Wbrew wywodzącemu się z badań nad językowym obrazem świata ogólnemu przekonaniu, że istnieje zależność między językiem a poznaniem, można stwierdzić, że w sferze doświadczenia mistycznego nie może być mowy o takiej zależności. Ostatecznie ugruntowuje tę obserwację także fakt, że język nie jest źródłem doznań, wglądów i specyficznej wiedzy mistyka i w ogóle nie jest niezbędny w życiu człowieka mistycznego. Konieczność języka pojawia się dopiero wtedy, gdy mistyk chce wyjść ze swoim komunikatem na zewnątrz i działać przez słowa. Kończąc, można stwierdzić, że nie każdy rodzaj poznania jest uwarunkowany przez język.

\section{Alicja Sakaguchi}

\section{Cognition beyond language. A case of a religious mystic experience and verbal expression thereof}

An analysis of the experiences, insights and proclamations by mystics and prophets from various epochs unveils the characteristics of individuals exposed to long experiences and holistic (or integral) cognition. A mystic transformation affects the mode of speaking and communicating with the world. Language with its stereotypical phrases and connotations certainly limits human cognition. However, in the process of their transpersonal experience, mystics go beyond this barrier and overcome cognitive limitations including the flaws of human language. In order to present an altogether "different" space of reality shared by mystics, and to share their proclamations and teaching with a large audience, mystics apply very specific linguistic tools like the metaphor, allegory, antithesis, paradox, analogy, symbol, quotations from the Bible, hyperbole, parallelism, chiasm and, last but not least, parable. An act of viewing the prophecy and epiphany-related language reflecting the authors' synoptic (mystic) awareness "from the inside" makes it possible to identify archetypal criteria of the mystic experience and to establish the correct meaning of the key expressions (the sacred) and sacral acts of speech.

KEY WORDs: integral cognition, gnosis, mystic experience, prophet experience, prophecy and epiphany-related language, transcendental acts (of speech), sacral transcendental acts (of speech), the sacred.

prof. zw. dr hab. Alicja Sakaguchi - pracownik kontraktowy na Uniwersytecie w Paderborn, a od 1986 roku we Frankfurcie nad Menem; od roku 2003 profesor nadzwyczajny w Instytucie Lingwistyki Stosowanej na Wydziale Neofilologii Uniwersytetu im. Adama Mickiewicza w Poznaniu; zainteresowania naukowe: lingwistyka ogólna i stosowana, języki fachowe i specjalistyczne, w szczególności język religijny, translatoryka, mistyka, teologia mistyczna, fenomenologia, esperantologia i interlingwistyka. 